\title{
Pembelajaran Bercerita bagi Peningkatan Apresiasi Imajinasi Siswa pada Mata Pelajaran Bahasa Indonesia
}

\section{Storytelling Learning to Increase Student's Imagination Appreciation in Indonesian Language Subjects}

\author{
Ani Hasanah \\ Sekolah Menengah Kejuruan Negeri 1 Bandung, Bandung, Jawa Barat, Indonesia \\ Email: nengumi60@gmail.com
}

Naskah diterima tanggal 09/10/2019, direvisi akhir tanggal 02/11/2019, disetujui tanggal 23/12/2019

\begin{abstract}
Abstrak
Latar belakang penelitian tindakan kelas ini adalah rendahnya prestasi belajar siswa kelas XI AP 1 SMKN 1 Bandung pada Mata Pelajaran Bahasa Indonesia. Kondisi ini diduga karena metode pembelajaran yang diterapkan monoton dan berpotensi membuat siswa jenuh. Oleh karena itu diadakan Penelitian Tindakan Kelas dengan penerapan pembelajaran bercerita. Adapun tujuan penelitian ini adalah untuk mengetahui apakah penerapan pembelajaran bercerita dapat meningkatkan prestasi belajar siswa kelas XI AP 1 SMKN 1 Bandung pada Mata Pelajaran Bahasa Indonesia. Penelitian ini menggunakan pendekatan kualitatif untuk mendapatkan datanya dan analisisnya melalui kajian reflektif dan kolaboratif. Adapun pelaksanaan tindakannya terdiri dari dua siklus dengan menerapkan pembelajaran bercerita. Berdasarkan hasil penelitian dapat diketahui bahwa aktivitas belajar siswa pada setiap siklus mengalami peningkatan, yaitu dari $41 \%$ pada siklus I, menjadi $65 \%$ pada siklus II dan $94 \%$ pada siklus III. Berdasarkan hasil penelitian dapat disimpulkan bahwa penerapan pembelajaran bercerita dapat meningkatkan prestasi belajar siswa pada mata pelajaran Bahasa Indonesia. Adapun saran peneliti adalah semua pihak baik kepala sekolah, guru dan siswa seharusnya bekerjasama dalam mengoptimalkan pembelajaran khususnya dengan menerapkan pembelajaran bercerita agar aktivitas siswa dan prestasi belajar siswa dapat terus ditingkatkan.
\end{abstract}

Kata kunci: Pembelajaran bercerita, Apresiasi Imajinasi Siswa

\begin{abstract}
The background of this class action research is the low student achievement in class XI AP 1 SMKN 1 Bandung in Indonesian Language Subjects. This condition is suspected because the learning method applied is monotonous and has the potential to make students bored. Therefore Classroom Action Research was conducted with the application of storytelling learning. The purpose of this study was to determine whether the form of storytelling learning can improve student achievement in class XI AP 1 SMKN 1 Bandung in Indonesian Language Subjects. This study uses a qualitative approach to obtain data and analysis through reflective and collaborative education. The implementation of the action consists of two cycles by applying storytelling learning. Based on the results of this study, it can be seen that the learning activities of students in each period have increased, namely from $41 \%$ in the first cycle to $65 \%$ in the second cycle and 94\% in the third cycle. Based on the results of the study, it can be concluded that the application of storytelling learning can improve student achievement in Indonesian subjects. The researcher suggests that all parties, including school principals, teachers, and students should work together to optimize learning, especially by implementing storytelling learning so that student activities and student achievement can continue to be improved.
\end{abstract}

Keyword: Storytelling learning, Student Imagination Appreciation 


\section{PENDAHULUAN}

Pembelajaran bahasa Indonesia dimaksudkan untuk meningkatkan kemampuan siswa dalam berkomunikasi berbahasa Indonesia yang baik dan benar, baik lisan maupun tulis, serta menumbuhkan apresiasi terhadap hasil karya kesastraan yang dimiliki oleh warga Indonesia (Pratiwi, 2016). Dalam pembelajaran bahasa indonesia salah satunya yakni keterampilan dalam berbicara sebagai kemampuan komunikatif siswa. Berbicara merupakan keterampilan yang dapat dilatih pada seseorang untuk mengeluarkan ide, gagasan, atau pikiran orang lain melalui lisan (Abidin, 2012; Madyawati, 2016; Pratiwi, 2016; Tarigan, 2008). Salah satu tujuan bercerita pada tingkat pertama adalah mengukur kemampuan peserta didik untuk mengungkapkan ide dan apa-apa yang diketahuinya dari cerita (Tambak, 2016). Sedangkan menulis dapat diartikan sebagai kemampuan seseorang untuk melahirkan pikiran, ide, perasaan, atau pengalaman dengan menggunakan lambang-lambang tertentu menggunakan tulisan sebagai mediumnya yang bersifat produktif dan ekspresif (Darmawan, 2019).

Pada pembelajaran bercerita (storytelling) menulis merupakan hal pokok yang harus di perhatikan sebelum bercerita. Menulis menjadi perhatian khusus baik oleh guru mata pelajaran atau pihak-pihak yang terkait dalam penyusunan kurikulum pembelajaran. Saat ini pembelajaran menulis lebih banyak disajikan dalam bentuk teori dan tidak banyak melakukan praktik menulis. Hal itu menyebabkan kurangnya kebiasaan menulis siswa, sehingga mereka sulit menuangkan ide mereka dalam bentuk tulisan. Setiap jenjang pendidikan pasti menggunakan kemampuan menulis siswa sebagai salah satu alat dalam menyampaikan kegiatan dalam proses pembelajaran. Keterampilan menulis yang tidak diimbangi dengan praktik menjadi salah satu faktor kurang terampilnya siswa dalam menulis (Azizah, 2019).

Siswa pada sekolah menengah kejuruan, seharusnya sudah lebih dapat untuk mengekspresikan gagasan, pikiran, dan perasaannya secara tertulis. Namun pada kenyataannya, kegiatan menulis belum sepenuhnya terlaksana, sejalan dengan yang dinyatakan oleh Chaniago, et al (2016) kesulitan siswa dalam menguasai keterampilan menulis dapat disebabkan oleh kesempatan latihan yang kurang baik, benar, dan sungguh-sungguh. Menyusun suatu gagasan, pendapat dan pengalaman menjadi suatu rangkaian berbahasa tulis yang teratur, sistematis, dan logis bukan pekerjaan mudah, melainkan pekerjaan yang memerlukan latihan terus-menerus. Menurut Akhadiah (2002) tidak berlebihan jika dikatakan bahwa kemampuan menulis merupakan kemampuan yang kompleks yang menuntut sejumlah pengetahuan dan keterampilan. Keberhasilan siswa dalam mengikuti kegiatan pembelajaran sangat ditentukan oleh kemampunannya dalam menulis, menjawab pertanyaan dan soal-soal ulangan yang bersifat uraian. Keterampilan menulis siswa merupakan kemampuan siswa dalam mengorganisasi pikirannya sehingga menjadi padu sesuai yang diharapkan siswa dan guru. Oleh karenanya pembelajaran keterampilan menulis mempunyai kedudukan yang sangat strategis dalam pendidikan dan pengajaran.

Dalam silabus mata pelajaran bahasa Indonesia kurikulum 13 (kurtilas) yang berbasis kompetensi, bahasa Indonesia diajarkan dalam tiga komponen, yaitu kebahasaan, pemahaman, dan penggunaan. Pada pelaksanaan pembelajaran, ketiga komponen tersebut dikemas secara terpadu dengan satu tema tertentu. Materi yang bersifat mengasah pemahaman dan pengetahuan kesastraan termasuk komponen kebahasaan, sedangkan apresiasi termasuk komponen penggunaan.

Salah satu tujuan umum pembelajaran bahasa Indonesia dalam garis besar program pengajaran tersebut adalah agar siswa mampu memahami, menikmati, dan memanfaatkan karya sastra untuk mengembangkan kepribadian, memperluas wawasan kehidupan, serta meningkatkan pengetahuan dan kemampuan berbahasa. Siswa memiliki kemampuan menggunakan bahasa Indonesia untuk meningkatkan 
kemampuan intelektual yang berpikir kreatif, menggunakan akal sehat, menerapkan pengetahuan yang berguna, memecahkan masalah, kematangan emosional dan sosial, sedangkan salah satu tujuan khusus adalah siswa mampu mengungkapkan gagasan, pendapat, pengalaman dan pesan secara lisan dan tertulis, dan siswa memiliki kegemaran menulis untuk meningkatkan pengetahuan dan memanfaatkannya dalam kehidupan sehari-hari, serta peka terhadap lingkungan.

\section{METODE PENELITIAN}

Penelitian ini merupakan penelitian tindakan kelas (PTK) yang dilaksanakan di SMK Negeri 1 Bandung Tahun Pelajaran 2018/2019. Penelitian tindakan kelas merupakan suatu upaya kegiatan yang dilaksanakan untuk mengamati kejadian-kejadian belajar mengajar untuk memperbaiki praktek dalam pembelajaran agar lebih berkualitas dalam proses sehingga hasil belajar menjadi lebih baik (Bahri, 2012 \& pembelajaran berbi, et al., 2015). Sekolah ini dipilih karena sebagai tempat peneliti sehari-hari melaksanakan tugas mengajar. Subyek pada PTK ini melibatkan 34 siswa (dipilih secara random) di kelas XI AP 1 SMK Negeri 1 Bandung Tahun Pelajaran 2018/2019. Kelas XI AP 1 siswanya heterogen terdiri aspek sosial ekonomi maupun tingkat kemampuan awal, agama, dan perilaku siswa. Memiliki permasalahan khusus utamanya dalam prestasi belajar Bahasa Indonesia, terutama keterampilan menulis. Penelitian ini dilaksanakan selama dua minggu yaitu pada tanggal 10 sampai 24 September 2018, dengan satu minggu tatap muka 2 kali dan 2 jam pelajaran.

Persiapan penelitian ini dilaksanakan melalui tiga siklus. Setiap siklus terdiri atas dua treatment. Tiap siklus dilaksankan dalam empat tahap kegiatan yaitu planning, acting, observing, dan reflecting (Arikunto, 2013; Wiriaatmadja, 2008). Sebelum melakukan intervensi, penelitian lebih dahulu menyebarkan angket dan memberikan tes awal guna mengetahui kondisi siswa. Setelah kondisi awal diketahui, kemudian diadakan tindakan intervensi melalui siklus-siklus.

Pada siklus I dilakukan dua treatment yaitu (1) Mendengarkan cerita dari guru secara cermat, kemudian menulis pokok- pokok cerita; dan (2) Menuangkan ide pokok gagasan cerita yang didengar dalam tulisan dalam bentuk kalimat-kalimat sederhana. Pada siklus II ini diberikan treatment sebagai berikut (1) Anak diberikan photocopy cerita untuk dibacanya, kemudian guru memberikan tugas berupa merangkum kembali apa yang telah dibacanya; dan (2) Guru memberikan penguatan dengan cara mengoreksi kesalahan tulisan yang dibuat siswa. Pada siklus III ini diberikan treatment sebagai berikut (1) Guru memberikan cerita yang baru untuk dibaca dan siswa menuliskan cerita tersebut dengan bahasa mereka sendiri. Guru memberikan kertas berwarna sebagai media penulisan; dan (2) Siswa membacakan isi cerita yang telah ditulis, sementara guru menunjuk siswa lain untuk mengoreksi isinya, bahasanya, serta ejaannya yang benar-benar tampak salahnya, misalnya penggunaan huruf besar, tanda titik, dan sebagainya.

Selama berlangsungnya treatment pada siklus selalu diamati oleh observer dan guru sejawat (dalam hal ini guru kelas XI) yang fungsinya sebgai kolaborator, untuk mengamati perubahan yang terjadi pada siswa dan guru. Hasil pengamatan ini selanjutnya dicatat dalam lembar observasi.

Pada siklus penelitian tahap persiapan dilaksanakan pada tanggal 3 September 2018 kegiatan yang dilaksanakan dalam tahap ini adalah: (1) Mempersiapkan angket untuk siswa; (2) Menyiapkan perangkat pembelajaran; (3) Menyiapkan bahan intervensi; (4) Menyiapkan cara menganalisis data; dan (5) Menyiapkan lembar pengamatan perilaku siswa dan guru di kelas dan menyusun alat evalusia untuk mengetahui tingkat keterampilan menulis siswa.

Sebelum penelitian dilaksankan terlebih dahulu dilakukan penyebaran angket dan pemberian tes awal penguasaan keterampilan menulis. Penyebaran angket tanggal 10 September 2018. Peneliti memberikan angket berupa daftar pertanyaan untuk diisi siswa selaku responden untuk mengetahui gambaran umum situasi pengetahuan umum, keterampilan dasar dan sikap atas kegiatan menulis. Tes awal berupa pemberian tugas mengarang sebuah cerita fiksi atau sebuah cerita yang pernah mereka dengar. Semua karangan siswa dikoreksi dengan 
pedoman profil karangan. Setelah mengetahui kondisi awal, selanjutnya peneliti mempersiapkan tindakan yang harus dilaksanakan pada siklus pertama, kedua dan ketiga.

Guna mengumpulkan data yang diperlukan selama penelitian berlangsung, peneliti menggunakan berbagai teknik pengumpulan data yaitu tes, angket, observasi, dan wawancara. Sedangkan instrumen yang dipakai adalah angket, pedoman wawancara, pedoman pengamatan tes, tes keterampilan menulis dengan cerita sebagai sarananya. Jenis penelitian ini adalah jenis penelitian tindakan, artinya bahwa dalam mencapai tujuannya penelitian ini melakukan skenario terlebih dahulu dan mengubahnya jika tampak kurang berhasil. Perubahan biasanya terletak pada metode yang tampak pada setiap siklus tindakan. Dengan adanya refleksi dan perbaikan diharapkan peningkatan hasil akan berpengaruh signifikan. Pengaruh itu meliputi peningkatan mutu hasil pencapaian belajar siswa.

\section{HASIL DAN PEMBAHASAN}

Saat ini pelajaran menulis lebih banyak disajikan dalam bentuk teori daripada praktek. Hal ini menyebabkan kurangnya kebiasaan menulis di kalangan siswa. Siswa jadi kurang trampil mengekspresikan gagasan,pikiran dan perasaannya dalam bentuk tulisan. Untuk pembelajaran sastra siswa dapat dilatih ketrampilan menyimak dengan mendengarkan suatu cerita atau dongeng yang dibacakan, kemudian siswa mendiskusikan dan menceritakan kembali isi cerita yang sudah didengarnya.

Pelatihan ketrampilan menulis dapat dilakukan secara terencana dan berkala sehingga siswa dapat benar-benar terlatih dalam menulis. Berbagai media pembelajaran dapat dilakukan sehingga ada berbagai macam variasi yang dilakukan dalam proses pembelajaran. Kenyataan umum dijumpai dalam pembelajaran bahasa Indonesia adalah kurangnya memberikan pelatihan-pelatihan menulis dan mengarang secara baik dan kontinyu. Guru terjebak pada pembelajaran cerita dengan bercerita sendiri sementara murid hanya mendengarkan. Dalam pembelajaran seharusnya bukan bahan pelajaran yang diutamakan, melainkan pengarahan, perhatian, dan pelatihan yang kontinyu sesuai dengan kemampuan dan minat siswa.

Berdasarkan latar belakang di atas ada beberapa permasalahan yang perlu dikaji, baik dari faktor internal yang berasal dari dalam diri siswa dan faktor eksternal yang berasal dari luar diri siswa. Masalah yang menjadi fokus penelitian ini adalah pembelajaranbercerita bagi peningkatan imajinasi siswa pada mata pelajaran bahasa Indonesia. Adapun rumusan masalahnya adalah bagaimana pengaruh pembelajaran bercerita bagi peningkatan apresiasi imajinasi siswa kelas XI AP 1 SMK N I Bandung.

Menulis adalah melukiskan atau menurunkan lambing-lambang grafik yang menggambarkan suatu bahasa yang dipahami oleh seseorang sehingga orang lain dapat memahami bahasa dan gambaran grafik itu (Tarigan, 2005).

Menurut Nadjib (2018) untuk mempercepat mengalirnya ide-ide, dia harus mengetik di lembaran-lembaran kertas HVS yang berwarna warni. Ini merupakan kiat ampuh seorang penulis. Untuk melakukan penelitian kemampuan menulis ini ada beberapa setting untuk penelitian yaitu seting lokasi, subjek, karakteristik siswa dan waktu penelitian.

Dalam pelaksanaannya penelitian ini dilaksanakan melalui tiga siklus, setiap siklus terdiri dari dua treatment. Tiap siklus dilaksanakan dalam empat tahap kegiatan yaitu planning, acting, observing, dan reflecting. Pertama menyebar angket dan memberikan tes awal guna mengetahui kondisi siswa.

Guna mengumpulkan data selama penelitian, peneliti menggunakan berbagai teknik pengumpulan data yaitu tes, angket, obsevasi dan wawancara. Jenis penelitian ini adalah penelitian tindakan artimya dalam mencapai tujuan penelitiannya melakukan scenario terlebih dahulu dan mengubahnya jika tampak kurang berhasil dengan adanya refleksi dan perbaikan diharapkan peningkatan hasil akan berpengaruh signifikan terhadap hasil pencapaian siswa.

\section{Persiapan Tindakan}

Pada awal penelitian, yaitu sebelum 
dilaksanakan treatment di kelas, peneliti terlebih dahulu menyebarkan angket dan tes awal kepada siswa guna mengetahui kondisi sesungguhnya. Selanjutnya hasil secara lengkap sebagai berikut:

a. 20 anak menyenangi kegiatan menulis. b. 8 anak tidak menyenangi kegiatan menulis.

c. 6 anak menyatakan kadang senang kadang tidak senang.

Sedangkan pada tes/penilaian siklus pertama menunjukkan

Tabel 1. Perolehan Skor Menulis Cerita Siklus I

\begin{tabular}{c|c|c|c|c|c}
\hline \multirow{2}{*}{ Kelas } & \multirow{2}{*}{$\begin{array}{c}\text { Skor Menulis } \\
\text { Cerita }\end{array}$} & \multirow{2}{*}{ Nilai } & Jumlah & \multicolumn{2}{|c}{ Hasil yang Diperoleh } \\
\cline { 5 - 6 } & $86-100$ & $\mathrm{~A}$ & 0 & 14 Anak & $0 \%$ \\
\hline & $70-85$ & $\mathrm{~B}$ & 4 & Atau $41 \%$ & $12 \%$ \\
\hline XI AP 1 & $60-69$ & $\mathrm{C}$ & 10 & & $29 \%$ \\
\hline & $50-59$ & $\mathrm{D}$ & 18 & & $53 \%$ \\
\hline & $<50$ & $\mathrm{E}$ & 2 & & $6 \%$ \\
\hline
\end{tabular}

Tabel 2. Perolehan skor menulis Cerita siklus II

\begin{tabular}{|c|c|c|c|c|c|}
\hline \multirow{2}{*}{ Kelas } & \multirow{2}{*}{$\begin{array}{l}\text { Skor Menulis } \\
\text { Cerita }\end{array}$} & \multirow{2}{*}{ Nilai } & \multirow{2}{*}{$\begin{array}{c}\text { Jumlah } \\
\text { Siswa }\end{array}$} & \multicolumn{2}{|c|}{ Hasil Yang Diperoleh } \\
\hline & & & & Tuntas & Presentase \\
\hline & $86-100$ & A & 0 & & $0 \%$ \\
\hline & $70-85$ & B & 8 & & $24 \%$ \\
\hline \multirow[t]{3}{*}{ XI AP 1} & $60-69$ & $\mathrm{C}$ & 14 & $\begin{array}{c}22 \text { Anak } \\
\text { atau } 65 \%\end{array}$ & $41 \%$ \\
\hline & $50-59$ & $\mathrm{D}$ & 12 & & $35 \%$ \\
\hline & $<50$ & $\mathrm{E}$ & 0 & & $0 \%$ \\
\hline
\end{tabular}

Tabel 3. Perolehan skor menulis Cerita siklus III

\begin{tabular}{|c|c|c|c|c|c|}
\hline \multirow{2}{*}{ Kelas } & \multirow{2}{*}{$\begin{array}{l}\text { Skor Menulis } \\
\text { Cerita }\end{array}$} & \multirow{2}{*}{ Nilai } & \multirow{2}{*}{$\begin{array}{c}\text { Jumlah } \\
\text { Siswa }\end{array}$} & \multicolumn{2}{|c|}{ Hasil Yang Diperoleh } \\
\hline & & & & Tuntas & Presentase \\
\hline & $86-100$ & A & 4 & & $12 \%$ \\
\hline & $70-85$ & $\mathrm{~B}$ & 16 & & $47 \%$ \\
\hline \multirow[t]{3}{*}{ XI AP 1} & $60-69$ & $\mathrm{C}$ & 12 & $\begin{array}{c}32 \text { Anak } \\
\text { atau } 94 \%\end{array}$ & $35 \%$ \\
\hline & $50-59$ & $\mathrm{D}$ & 2 & & $6 \%$ \\
\hline & $<50$ & $\mathrm{E}$ & 0 & & $0 \%$ \\
\hline
\end{tabular}

\section{Hasil Tindakan}

Dari data yang diperoleh pada siklus

Tabel 4. Peningkatan dan Penurunan Skor Menulis Cerita

\begin{tabular}{c|c|c|c|c|c}
\hline $\begin{array}{c}\text { Skor Menulis } \\
\text { Cerita }\end{array}$ & Nilai & Siklus I & Siklus II & Siklus III & $\begin{array}{c}\text { Peningkatan/ } \\
\text { Penurunan }\end{array}$ \\
\hline $86-100$ & A & 0 & 0 & 4 & $0+, / 4+$ \\
\hline $70-85$ & B & 4 & 8 & 16 & $4+, / 8+$ \\
\hline $60-69$ & C & 10 & 14 & 12 & $4+, / 2-$ \\
\hline $50-59$ & D & 18 & 12 & 2 & $6-, / 10-$ \\
\hline$<50$ & E & 2 & 0 & 0 & $2-, / 0$ \\
\hline
\end{tabular}

Keterangan: Dikatakan tuntas apabila siswa mampu meraih nilai minimal C atau $60 \mathrm{ke}$ atas. Jika dibawahnya maka dianggap tidak tuntas. 
Dari tabel 4 tersebut di atas dapat ditarik kesimpulan bahwa banyaknya siswa yang mampu dan menguasai keterampilan menulis cerita ditemukan adanya peningkatan yang signifikan. Banyaknya siswa yang tuntas mengarang siklus I berjumlah 14 atau $41 \%$, naik menjadi II berjumlah 22 atau dari $65 \%$ dan terakhir siklus III berjumlah 32 atau 94\%. Berarti ada anak tidak tuntas dalam pembelajaran ini berjumlah 2 orang. Sementara itu yang tidak menguasai cenderung menurun dari 20 menjadi 12, kemudian, 2. Atau dari $56 \%$ menjadi $35 \%$ dan terakhir $6 \%$.

Gambar 1. Peningkatan Siswa yang Menguasai Keterampilan Menulis cerita

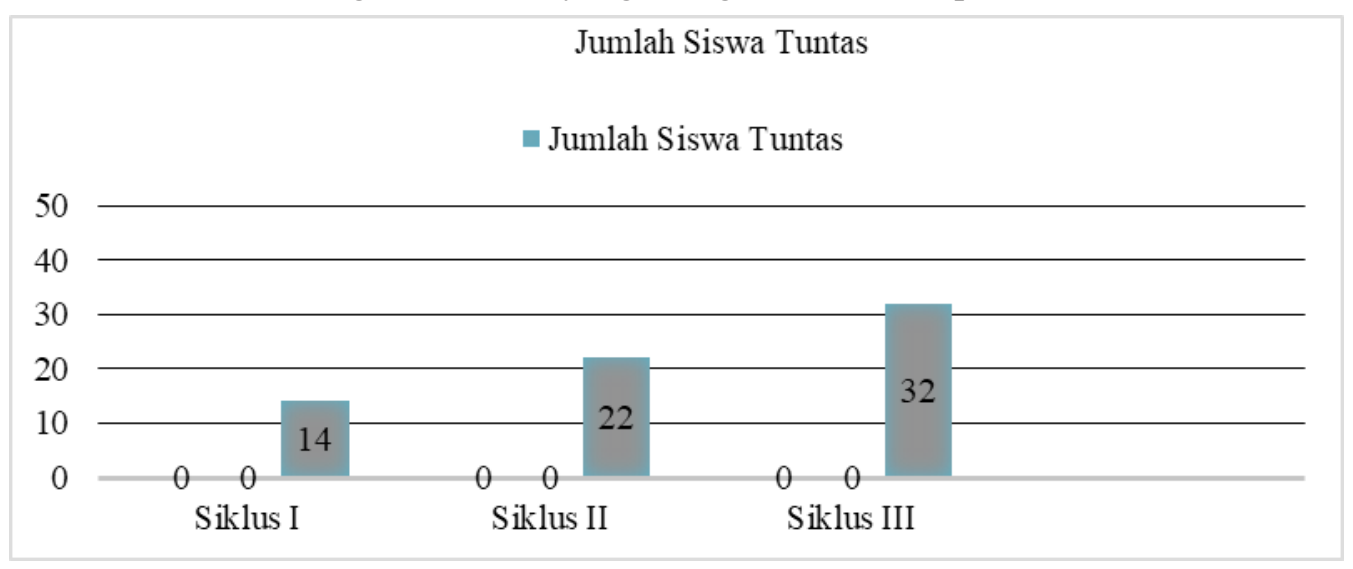

Gambar 2. Penurunan Siswa yang Tidak Menguasai Keterampilan Menulis cerita

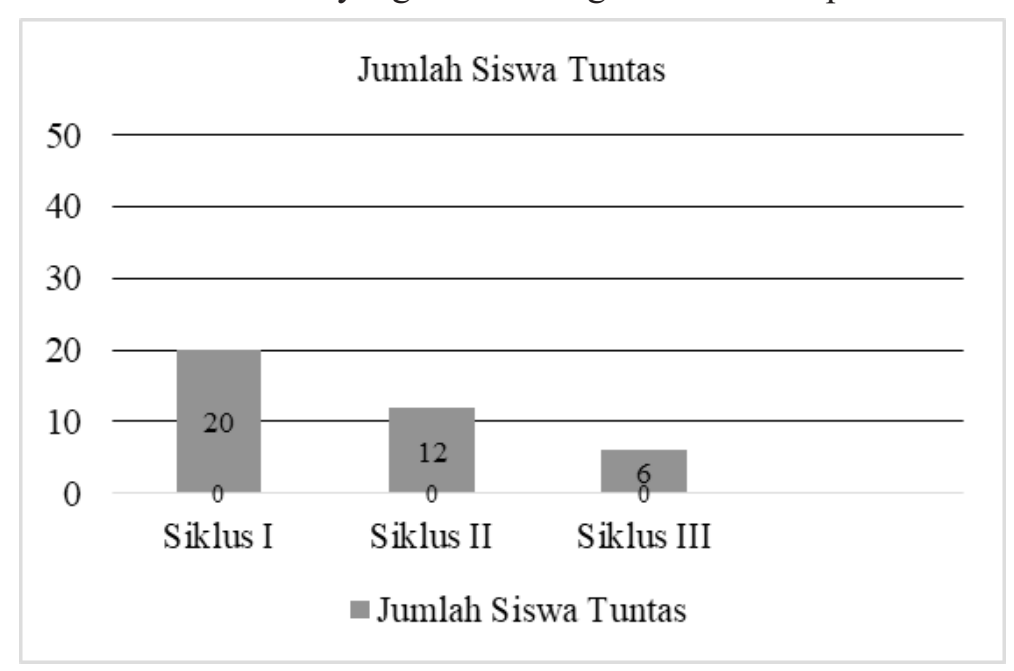

\section{Pembahasan Atas Hasil Tindakan \\ a) Siklus 1}

Selama berlangsungnya siklus pertama, siswa mengalami kemajuan dan perkembangan yang cukup berarti yang pertama siswa sangat berminat dengan metode pembelajaran menulis cerita, meskpun hasilnya belum baik yaitu nilai ketuntasan sebesar $41 \%$ yang mampu menulis dengan baik. Hasil dapat dilihat dari hasil pengamatan dan observasi yang dilakukan. Tampaknya bahwa siswa sangat menikmati jika guru menyampaikan cerita dalam bentuk cerita lisan. Namun akibatnya adalah siswa hanya paham, tetapi tidak mampu menyampaikan lagi secara lisan kepada orang lain dalam bentuk tulisan.

\section{b) Siklus 2}

Kemajuan yang dicapai dalam siklus kedua, menambah semangat siswa untuk menulis kembali dengan media kertas berwarna yang disediakan. Dengan sedikit sentuhan berupa pembetulan kesalahan sedikit dari rangkuman yang mereka lakukan, maka nilai ketuntasan sedikit lebih baik yaitu mencapai $65 \%$. Artinya telah lebih dari setengah jumlah siswa mampu menulis cerita dengan lebih baik. 
Bimbingan dana arahan guru cukup memberikan atas kepahaman siswa sehingga nilai yang diperoleh juga cukup baik bahkan lebih baik dibandingkan siklus pertama. Artinya ada peningkatan yang lebih tinggi yaitu mencapai 8 poin yaitu selisih dari $14 \mathrm{ke}$ 22 atau $24 \%$.

\section{c) Siklus 3}

Tampak kemajuan yang luar biasa di siklus 3 ini. Meskipun demikian, masih ada dua siswa yang dianggap belum tuntas, karena belum mencapai skor minimal yaitu 34. Peningkatan mencapai 10 poin dari 22 menjadi 32 atau kenaikannya mencapai $29 \%$.

Diskusi untuk melihat kesalahan milik kawan ternayata berpengaruh positif atas hasil yang dicapai siswa. Para siswa saling bersaing untuk memperoleh nilai tertinngi. Satu sama lain memuji kelebihan dan kekurangan teman yang lain. Dengan saling melihat keterangan ini pula siswa dapat belajar dari kesalahan teman atau dirinya sendiri.

Penggunaan media penunjang seperti infocus juga sedikit menunjang pembelajaran. Sementara dengan suasana rileks dan santai sambil bermain mampu membuat siswa lebih bebas mengekspresikan kemampuannya dalam menulis. Suasana santai, penuh tawa, serta penuh kebebasan justru membuat siswalebih kreatif. Kertas berwarna semakin menyemarakkan suasana kelas yang biasanya didominasi warna cat putin tembok sekolah, menjadi lebih meriah.

\section{KESIMPULAN}

Bobot sebuah tulisan atau artikel ditentukan oleh lima unsur yang membangunnya. Kelima unsur itu adalah (1) Ide/gagasan, (2) Organisasi, (3) Struktur, (4) Diksi/pilihan kata, (5) Ejaan. Semakin baik penguasaan kelima elemen tersebut, maka semakin berbobot pula tulisan atau artikel yang dihasilkan. Permasalahan rendahnya ketrampilan siswa kelas XI AP 1 SMK Negeri 1 Bandung, dalam pembelajaran bercerita bagi peningkatan imajinasi siswa dengan tema mengubah artikel menjadi cerpen pada mata pelajaran Bahasa Indonesia menjadi perhatian.

Dengan berbagai metode bervariasi dan media pembelajaran menulis ternyata mampu meningkatkan motivasi, dan kemampuan menulis cerita secara signifikan, artinya bahwa suasana yang tidak membosankan di kelas mampu memberi kontribusi positif terhadap peningkatan kemampuan siswa dalam menuliskan kembali cerita yang pernah mereka baca.

Dengan model pembelajaran seperti ini pula ternayata kelas menjadi lebih hidup dan ceria. Siswa yang bisanya hanya diam dan membisu tampak mulai berani bicara dan mengungkapkan pendapat. Dalam hal ini berarti keterampilan menulis seperti ini juga mampu meningkatkan keterampilan yanglain, yaitu berbicara dan membaca serta mendengarkan. Pintu menulis ternyata mampu juga mendongkrak tiga keterampilan berbahasa yang lain.

\section{DAFTAR RUJUKAN}

Akhadiah, S. (2002). Pembinaan Kemampuan Menulis Bahasa Indonesia. Jakarta: Erlangga.

Ananda, R., Rafida, T., \& Syahrum. (2015). Penelitian Tindakan Kelas. Bandung: Citapustaka Media.

Arikunto, S. (2013). Prosedur Penelitian Suatu Pendekatan Praktik. Edisi Revisi. Jakarta: PT. Rineka Cipta.

Azizah, E. (2019). Media Berita Tingkatkan Keterampilan Menulis Cerpen. [Online]. DIakses dari: https:// radarkudus.jawapos.com/read/2019/04/11/131138/media-berita-tingkatkan-keterampilan-menuliscerpen.

Bahri, A. (2012). Penelitian Tindakan Kelas. Makassar: Universitas Muhammadiyah Makassar.

Chaniago, S. M., Badusah, J., \& Embi, M. A. (2016). Masalah Pengajaran Kemahiran Berbahasa di Sekolah di Indonesia. Jurnal Pendidikan Bahasa Melayu, 1 (1), 109-112.

Darmawan, A. (2019). Pembelajaran Keterampilan Menulis Berdasarkan Kurikulum 2013. [Online]. Diakses dari: $\quad$ https://radarkudus.jawapos.com/read/2019/10/08/159749/pembelajaran-keterampilan-menulisberdasarkan-kurikulum-2013.

Gabriel, Y. (2000). Storytelling in organizations: Facts, fictions, and fantasies. New York: Oxford University Press.

Madyawati, L. (2016). Strategi Pengembangan Bahasa pada Anak. Jakarta: Prenadamedia Group. 
Nadjib, E. A. (2018). Gelombang Kreativitas. [Online]. Diakses dari: https://www.caknun.com/2018/gelombangkreativitas/.

Pratiwi, R. R. (2016). Penerapan Metode Storytelling untuk Meningkatkan Keterampilan Berbicara Siswa Kelas II SDN S4 Bandung. Jurnal Pendidikan Guru Sekolah Dasar, Vol 1(1), hlm. 199-207.

Tambak, S. (2016). Metode Bercerita dalam Pembelajaran Pendidikan Agama Islam. Jurnal Al-Thariqah, Vol. 1(1), hal 1-27.

Tarigan, D. (2005). Membina Keterampilan Menulis Kertas Paragrap dan Pengembangannya. Bandung: PT Angkasa.

Tarigan, H. G. (2008). Membaca Sebagai Suatu Keterampilan Berbahasa. Bandung: Angkasa.

Wiriaatmadja, R. (2008). Metode Penelitian Tindakan Kelas untuk Meningkatkan Kinerja Guru dan Dosen / Rochiati Wiriaatmadja. Bandung: Remaja Rosdakarya. 